CHAPTER 16

\title{
2019 AII B Law Lecture: The Rise of Sustainable Development in International Investment Law
}

\author{
Nico Schrijver*
}

\begin{abstract}
In recent decades, sustainable development gained currency as a principle of international law remarkably quickly. It is an integrated concept, having economic, environmental, social and governance dimensions. Sustainable development is by now well anchored in various sources of international law, especially treaty law and soft law instruments, and ranging from international environmental law and human rights law to international economic law and investment law. As to the latter, (inter-)regional economic treaties and bilateral investment treaties increasingly incorporate sustainable development. This also gave rise to the concept of responsible investment, which is an approach to conducting business and managing assets that includes environmental, social and governance factors as well as taking public values into account in investment strategy. The UN General Principles of Business and Human Rights (Ruggie Principles) and the Sustainable Development Goals of the World Development Agenda 2030 are closely related to the evolution of the principles for responsible investment. Obviously, many obstacles to their implementation do exist. These include the lack of enforcement mechanisms, controversial investment practices and widespread patterns of unsustainable production and consumption. This chapter concludes by examining what the role of international investment law, both as a value system and a concrete regulatory framework, can be for achieving sustainable development and responsible investment.
\end{abstract}

\section{Introduction}

This lecture examines the rise of sustainable development in international investment law. For this purpose, the meaning of the concept of sustainable

* Nico Schrijver, Member and President (2017-2019) of the Institut de Droit International, State Councillor of the Council of State of the Netherlands and professor of international law at Leiden University, n.j.schrijver@law.leidenuniv.nl.

(C) ASIAN INFRASTRUCTURE INVESTMENT BANK (AIIB), 2021 | DOI:10.1163/9789004441033_017

This is an open access chapter distributed under the terms of the CC-BY-NC 4.o License. 
development and its inception into international law is first discussed (Section 1). Secondly, the gradual incorporation of sustainable development into international investment law and the emergence of the concept of 'responsible investment' is addressed (Section 2). Obviously, many obstacles do still exist for the implementation of the principles and rules of sustainable development and responsible investment. Therefore, the last part of this lecture (Section 3) discusses how to overcome these obstacles and what the role of international law in general and international investment law in particular can be in achieving sustainable development and responsible investment.

2

\section{The Meaning of Sustainable Development and Its Inception into International Law}

'Sustainable development' is a key term in international politics which in a remarkably short period of time has also become firmly established in international law. ${ }^{1}$ The World Commission on Environment and Development headed by former Prime Minister Brundtland of Norway defines this concept in its report 'Our Common Future' as development that "meets the needs of the present generation without compromising the ability of future generations to meet their own needs". ${ }^{2}$ This is still an admirably concise description of the core of the meaning of sustainable development. Firstly, this description demonstrates an awareness of the finite capacity of our planet and its natural resources. Second, it also takes into account the interests of future generations, including our grandchildren, to meet their own needs, hence highlighting the principle of intergenerational equity.

In a way, sustainable development builds on and combines three principal chapters of international law. Firstly, international environmental law, which is a relatively young chapter of international law; ${ }^{3}$ second, international economic law, especially as far as it relates to development; ${ }^{4}$ and third, human rights law. ${ }^{5}$ This lecture refers both to substantive rights- such as the right to life, the right to health and the right to an adequate living standard - and to procedural human rights—-such as citizens' access to information, access to

1 Schrijver, The Evolution of Sustainable Development in International Law 2008, 173-207; also in The Hague Academy of International Law (ed), Collected Courses of the Hague Academy of International Law 2007, vol 329, 217-412.

2 World Commission on Environment and Development 1987, 43.

3 See Sands and Peel 2018; Birnie and others 2009.

4 See Schrijver and Weiss 2004; Bhuiyan and others 2014.

5 See Danish Institute for Human Rights, 'Human Rights and Sustainable Development', 13 July 2018. 
justice and participation in environmental decision-making. Hence, in a way, sustainable development represents the best of all worlds.

The work of the present author has distinguished seven main elements of the principle of sustainable development. ${ }^{6}$ The first, and perhaps the most firmly grounded in international law, is the sustainable use of natural resources. Many treaties now emphasize this dimension, whether in relation to fishery agreements, sustainable timber production or preserving biological diversity. Second, also very important, is sound macroeconomic development and what the facilitating role of international law can be toward this end. The third element is environmental conservation, a key component of sustainable development. The fourth is equity, both between current and future generations (that is intergenerational equity), but also equity for and among the people living now: that is intra-generational equity. Fifth, there is the element of time. The time dimension of sustainable development is both short and long-term. This is particularly evident in the Paris Climate Agreement. ${ }^{7}$ In the short-term, we have to act now if we would like to prevent further destruction of the precious planetary climate system. But there is also a need for a sustained, long-term strategy. In terms of the Paris Agreement: by 2050 we should operate as energyneutral as much as possible and by 2100 , the global temperature rise should be well below two degrees Celsius. ${ }^{8}$ Element number six relates to human rights, public participation and justice for all. Lastly, number seven, perhaps the most important but at the same time the most complicated element, is how to integrate the environmental, the developmental and the human rights concerns and how to blend them into a comprehensive integrated and effective international law system in the pursuance of sustainable development. ${ }^{9}$

Sustainable development did not come about overnight in international law. Its roots can be traced to some early treaties, for example, nature management treaties and anti-pollution in river treaties, some of which even date back to the nineteenth century. Furthermore, we can also note the concept of the maximum sustainable yield in international fisheries law of the early part of the twentieth century. ${ }^{10}$ Yet the concept of sustainable development was really launched through so-called soft law in the period of the United Nations. In particular, the 1972 Stockholm Declaration ${ }^{11}$ and the 1992 Rio Declaration on

\footnotetext{
6 Schrijver, The Evolution of Sustainable Development in International Law 2008, 208-219.

7 Paris Agreement.

8 Ibid., art 2, para 1(a).

9 See New Delhi Declaration of Principles of International Law Relating to Sustainable Development, princ 7 .

10 Cf UN Convention on the Law of the Sea (UNCLOS), arts 61(3) and 119(1).

11 See UN, 'Report of the United Nations Conference on the Human Environment', 16 June 1972, 3-5. For a comprehensive analysis of the debates and the text, see Sohn 1973.
} 
Environment and Development ${ }^{12}$ have been instrumental in putting sustainable development high on the international political agenda. In their track, soon new multilateral environmental agreements were concluded. Examples of follow ups of the Stockholm Declaration include the Convention on International Trade in Endangered Species (CITES, 1973), ${ }^{13}$ the Convention on Wetlands of International Importance especially as Waterfowl Habitat $(1974)^{14}$ and the Convention on Long-Range Transboundary Air Pollution (CLRTAP, 1979). ${ }^{15}$ Off-springs of the Rio Declaration include the first Climate Change Convention (UNFCC) ${ }^{16}$ and the Convention on Biological Diversity (both from 1992), ${ }^{17}$ in addition to the earlier adopted Ozone Convention and its Montreal Proto$\mathrm{col}$, which have proven to be effective for the protection of the ozone layer. ${ }^{18}$ Furthermore, we now see the incorporation of the principle of sustainable development also in international economic agreements. The agreement to establish the World Trade Organization adopted in 1994 serves as an important example since it integrates sustainable development as an important objective of this new international economic institution. ${ }^{19}$

In Europe, we can also note that the 2007 Reform Treaty of Lisbon on the Functioning of the European Union (EU) includes as many as 27 references to the concept of sustainable development. ${ }^{20}$ Somewhat hesitantly behind are human rights treaties as well as international investment agreements, but that may be a matter of time.

Apart from consolidating and codifying sustainable development in treaty law, soft law is instrumental in further clarifying and progressively developing the scope and meaning of sustainable development. This brings us to the role of the Sustainable Development Goals (sDGs), adopted in 2015. ${ }^{21}$ Their forerunners are the eight Millennium Development Goals, adopted at the

12 Declaration of the United Nations Conference on Environment and Development (Rio Declaration).

13 Convention on International Trade in Endangered Species of Wild Fauna and Flora (CITES).

14 Convention on Wetlands of International Importance especially as Waterfowl Habitat (Ramsar Convention).

15 Convention on Long-Range Transboundary Air Pollution (CLRTAP).

16 United Nations Framework Convention on Climate Change (UNFCCC).

17 Convention on Biological Diversity (Biodiversity Convention).

18 Vienna Convention for the Protection of the Ozone Layer (Vienna Convention); Montreal Protocol on Substances that Deplete the Ozone Layer (Montreal Protocol).

19 See the preamble of the Marrakesh Agreement establishing the wто (wто Agreement).

20 Treaty of Lisbon Amending the Treaty on European Union and the Treaty Establishing the European Community (Treaty of Lisbon).

21 UN, 'Sustainable Development Goals'. 
beginning of this millennium. ${ }^{22}$ In 2015 , they have been succeeded by 17 SDGs with as many as 169 targets. ${ }^{23}$ They are part and parcel of the wider United Nations World Development Agenda 2015 to 2030. ${ }^{24}$ These SDGs are of course not hard law, but they do carry some important normative value. It could well be argued that in part they embody 'programmatory' law and 'aspirational' law, in the sense of guidelines for the desirable future development of international law in support of sustainable development. ${ }^{25}$ The SDGs also have concrete targets and include monitoring, reporting and evaluation procedures. Many governments, international organizations, and non-state actors, including businesses, have subscribed to the SDGs. ${ }^{26}$ The various elements of the concept of sustainable development as discussed above, come clearly to the fore. For example, SDG 1 is that of poverty reduction ('leaving nobody behind'); SDG 3-of paramount interest to all of us - relates to good health; SDG 6 on the availability and sustainable management of water and sanitation for all; SDG 13 on combating climate change and its impacts; SDG 14 on conserving and sustainably using the oceans, seas and marine resources; SDG 15 on the sustainable use of terrestrial ecosystems, forests and biological diversity; SDG 16 refers to promoting peaceful and inclusive societies for sustainable development, providing access to justice for all and building effective, accountable and inclusive institutions at all levels. ${ }^{27}$ To achieve this, we need cooperation. This is also amply reflected in SDG 17 on global partnership for the achievement of the global goals. ${ }^{28}$

There is also an increasing body of international jurisprudence including from the International Court of Justice. ${ }^{29}$ In the Danube Dam case between Slovakia and Hungary for the first time in 1997, in the Pulp Mills case between Argentina and Uruguay in 2010 and most recently in the case between Costa Rica and Nicaragua regarding certain activities and the construction of a road by Nicaragua in the border area, we can note the Court's recognition of sustainable development as a concept in international law. ${ }^{30}$

22 UN Millennium Declaration. An extensive analysis of the substance and the state of affairs of the Millennium Development Goals is given by UNDP in Human Development Report 2003; and in the annual Millennium Development Goals Reports.

23 For a general overview of the SDG-making process, see Kamau and others 2018.

24 UN, 'Transforming Our World', 25 September 2015.

25 For the notion of 'programmatory' law, see Dupuy 1977, 245-258.

26 See Weiss and Browne 2014.

27 UN, 'Sustainable Development Goals'.

28 Ibid.

29 See Sands 1999, 390-396; Stephens 2010, 55-56.

30 Ibid. 
In sum, we can amply note the rise of sustainable development in international law: firstly, in areas of direct environmental relevance, such as rivers, seas, oceans, water resources, biological diversity, living and non-living natural resources and transboundary resources. In many of these fields, there has been intensive treaty-making. But now sustainable development is also on the rise in some other areas, such as trade agreements, economic cooperation treaties, rights of indigenous peoples, trade and investment and protection of the environment during armed conflict. ${ }^{31}$

What about sustainable development in international investment law? That is Section 3 of this lecture.

\section{Sustainable Development in International Investment Law}

International investment law is the branch of international law that deals with the promotion and protection of foreign investment as well as with the regulation of its activities. ${ }^{32}$ Traditionally, it was focused on how to minimize risks and how to maximize benefits for foreign investors as well as for capital importing countries. ${ }^{33}$ For long, there was hardly a relationship between international investment law on the one hand and international environmental law and sustainable development on the other. ${ }^{34}$ Currently, a trend can be noted in international investment law to address also the impacts of foreign investment that go beyond the economic and financial domain. For in recent decades, the impact of investment activities has given rise to significant political, environmental, human rights, sustainable development and other public interest concerns. ${ }^{35}$ In response, quite some transformation is taking place in modern international investment law in this regard. For example, trends can be discerned toward recognizing the need for expanding the regulatory space of States for public policies and toward subjecting foreign investment increasingly to duties. Examples of these public policy concerns include compliance with labour standards, respect for human rights and promotion of sustainable development and public health. These public policy concerns are leaving their marks on international arbitration, albeit hesitantly. ${ }^{36}$

\footnotetext{
31 Dam-de Jong 2015.

32 See Muchlinski and others 2008.

33 Schwarzenberger 1969.

34 See Schrijver, Sovereignty over Natural Resources 1997, ch 4, 120-142.

35 See the analysis by Subedi 2016; Chi 2018.

36 See Beharry and Kuritzky 2015, 383-429; Marley 2014, 1003-1039; Kube and Petersmann $2016,65^{-113}$
} 
International investment law is based on a variety of sources. They include international investment agreements (bilateral, regional, multilateral), customary international law norms, general principles of law, national investment law and soft law norms. In most of these sources, sustainable development, as a concern, is a late comer in international investment law. ${ }^{37}$ Only recently is it starting to manifest itself.

As regards existing investment agreements, few of those in force do refer to sustainable development and environment. However, this is changing because there is a clear trend among the newest treaties to address labour, environmental and sustainable development concerns. ${ }^{38}$

For example, the Comprehensive Economic and Trade Agreement between the EU and Canada, commonly known as CETA, contains a separate chapter on sustainable development (Chapter 23), next to chapters on labour and the environment. ${ }^{39}$ Similarly, the Comprehensive and Progressive Trans-Pacific Partnership Agreement (C PTPP) contains chapters on labour, the environment and development. ${ }^{40}$ Furthermore, in negotiation instructions, for example for the China-EU bilateral investment treaty (вІт) — called the Comprehensive Agreement on Investment - the parties have made it clear that the BIT should also build upon the SDGs. ${ }^{41}$

A similar trend can be noted when examining the most recent BITs. Most of the newly concluded treaties after 2014 contain clauses related to sustainable development. These can be in the form of general references to protection of the environment or promoting sustainable development in the preamble or more specific substantive provisions in the body of the BITs such as, for example, by preserving regulatory space for public policies of host States and discouraging parties to relax environmental standards in an effort to attract foreign investment. This trend can also be noted in recent Model BITs. This lecture will use the Netherlands as a point of reference, but could also have taken the US Model BIT or that of Belgium-Luxembourg as examples. ${ }^{42}$ On 22

37 See the analysis by Chi 2018.

38 See Prislan and Zandvliet 2015.

39 Comprehensive Economic and Trade Agreement between Canada, of the One Part, and the European Union and its Member States, of the Other Part (CETA between the EU and Canada), especially chs 23 (sustainable development), 24 (labour) and 25 (environment). Comprehensive and Progressive Agreement for the Trans-Pacific Partnership (CPTPP), respectively chs 19 (labour), 20 (environment) and 23 (development).

41 See Bian and Li 2020, 40-53. See also Chi 2018, 167.

422012 US Model BIT; 2019 Belgium-Luxembourg Economic Union Model BIT. 
March 2019, the Netherlands published its new model BIт. ${ }^{43}$ The amended text serves as a policy response to the changing economic landscape and the rise of public values and the increasingly leading role of the EU in the field of foreign investment regulation as a result of the Lisbon Reform Treaty on the EU; but also to discontent concerning the Dutch liberal coverage of investor and investment in its BIT, enabling many shell companies and sandwich corporations to benefit from protection under Dutch BITs. Furthermore, in the Netherlands and in the $\mathrm{EU}$ at large there is a clear tendency in favour of strengthening the right of the state to regulate, especially on environment and sustainable development issues as well as combating tax avoidance. Among the objectives of the new Dutch Model BIT feature the goals to attract and promote "responsible foreign investment" and "contribute to sustainable economic development". ${ }^{4}$ The model BIT refers at nine places to sustainable development and includes an extensive Article 6 entitled 'Sustainable development', consisting of seven clauses:

Article 6-Sustainable development

1. The Contracting Parties are committed to promote the development of international investment in such a way as to contribute to the objective of sustainable development.

2. Each Contracting Party shall ensure that its investment laws and policies provide for and encourage high levels of environmental and labour protection and shall strive to continue to improve those laws and policies and their underlying levels of protection.

3. The Contracting Parties emphasize the important contribution by women to economic growth through their participation in economic activity, including in international investment. They acknowledge the importance of incorporating a gender perspective into the promotion of inclusive economic growth. This includes removing barriers to women's participation in the economy and the key role that genderresponsive policies play in achieving sustainable development. The Contracting Parties commit to promote equal opportunities and participation for women and men in the economy. Where beneficial, the Contracting Parties shall carry out cooperation activities to improve

43 The full text of the 2019 Netherlands Model Investment Agreement is available at: $<$ https://investmentpolicy.unctad.org/international-investment-agreements/treatyfiles/5832/download $>$ accessed 8 March 2020. 
the participation of women in the economy, including in international investment.

4. The Contracting Parties recognize that it is inappropriate to lower the levels of protection afforded by domestic environmental or labour laws in order to encourage investment.

5. A Contracting Party shall not adopt and apply domestic laws contributing to the objective of sustainable development in a manner that would constitute unjustifiable discrimination or a disguised restriction on trade.

6. Within the scope and application of this Agreement, the Contracting Parties reaffirm their obligations under the multilateral agreements in the field of environmental protection, labor standards and the protection of human rights to which they are party, such as the Paris Agreement, the fundamental [International Labour Organization] Conventions and the Universal Declaration of Human Rights. Furthermore, each Contracting Party shall continue to make sustained efforts towards ratifying the fundamental [International Labour Organization] Conventions that it has not yet ratified.

7. The Contracting Parties are committed to cooperate as appropriate on investment-related sustainable development matters of mutual interest in multilateral fora. ${ }^{45}$

This Dutch Model BIT reflects the clear trend not to seek the lowering of protection in domestic environmental law or labour law so as to encourage foreign investment and clearly reaffirms state obligations under multilateral treaties, such as fundamental International Labour Organization (ILO) conventions and the Paris Climate Agreement. In addition, stricter definitions on both 'investment' and 'investor' have been included in Article 1 of the Dutch Model віт. ${ }^{46}$ In order to qualify under the terms of the вIт a legal person must have "substantial business activities" in the territory of the Contracting Party. ${ }^{47}$ (This means that the so-called 'Salini criteria' are incorporated in the вгт.48) Furthermore, some new obligations are incumbent upon the Contracting Party, including: good administrative behaviour; providing access to affective mechanisms of dispute resolution; and protecting against business-related

$45 \quad$ Ibid., art 6.

46 Ibid., art 1(a)-(b).

47 See Ibid., art $1(\mathrm{~b})(\mathrm{ii})$.

48 See, for example, ICsid, Salini Costruttori S.p.A. and Italstrade S.p.A. $v$ Kingdom of Morocco 2001, paras $5^{2-58}$. 
human rights abuses. ${ }^{49}$ Moreover, it is notable that some new obligations have been formulated for investors in the sense that they have to demonstrate corporate social responsibility. ${ }^{50} \mathrm{~A}$ last notable feature to mention is the clear preference for the establishment of a Multilateral Investment Court rather than continuing investor-State dispute settlement through ad hoc or institutionalized international arbitration. ${ }^{51}$

An important normative role is also played by all kinds of soft law instruments, most notably well-drafted declarations, guidelines and general principles in the context of international organizations. Early examples include the Organisation for Economic Co-operation and Development Guidelines on Multinational Enterprises (1976, revised in 2011), the ILO Tripartite Declaration on Social Policies and Employment (1977, revised in 2017), the ILO Declaration on Fundamental Principles and Rights at Work (1998) and the UN Global Compact (2004), initiated by former UN Secretary-General Kofi Annan. ${ }^{52}$ Closely related are the Principles for Responsible Investment (PRI), launched in 2006, which is an investor initiative in partnership with the UN Environment Programme, the Finance Initiative and the UN Global Compact. ${ }^{53}$

More recent efforts incorporate sustainable development more clearly. Key documents in this regard are the UN Guiding Principles on Business and $\mathrm{Hu}-$ man Rights, also known as the Ruggie Principles and endorsed by the Human Rights Council in 2011. ${ }^{54}$ These 31 Guiding Principles come under the three pillars of Protect, Respect and Remedy (PRR), which reflect corporate social responsibility and human rights diligence in a variety of ways. ${ }^{55}$ They have been further elaborated as regards sustainable development in:

- The UnCTAD Comprehensive Investment Policy Framework for Sustainable Development; 56

- The Sustainability Framework of the International Finance Corporation (IFC), member of the World Bank Group; 57

49 See 2019 Netherlands Model Investment Agreement, art 5.

$50 \quad$ Ibid., art 7.

51 Ibid., art 15 .

52 OECD 2011; ILO, Tripartite Declaration of Principles concerning Multinational Enterprises and Social Policy; ILo Declaration on Fundamental Principles and Rights at Work and its Follow-up; UN, 'The Global Compact Leaders Summit 2004—Final Report', 24 June 2004. See UN, 'Principles for Responsible Investment'.

54 See UN, 'Guiding Principles on Business and Human Rights', 21 March 2011.

55 See Ruggie 2013 .

56 See Chi 2018, 28-30.

57 IFC Sustainability Framework. 
- Numerous self-regulatory codes of conduct of industry and individual businesses; 58

- A Renewed EU Strategy 2011-14 for Corporate Social Responsibility; 59 and

- The AIIв Environmental and Social Framework, adopted in 2016.60

Of course, here I should also mention SDG 8 on 'Decent Work and Economic Growth'. Its targets include promoting policies that focus on entrepreneurship, creativity and innovation. They may well relate to sustainable development and responsible investment since they aim at creating jobs that stimulate economic growth without harming the environment. ${ }^{61}$

\subsection{Key Decisions of International Courts and Tribunals}

Also mentioned under this sub-section is the integration of sustainable development in the decisions of international courts and tribunals. Section 2, above, already referred to some cases before the International Court of Justice in which sustainable development was recognized as a relevant legal concept, including the Danube Dam case, the Pulp Mills case and the Certain Activities Carried Out by Nicaragua in the Border Area (Costa Rica v Nicaragua) case. We can also identify an increasing number of environment-related, sometimes sustainable development-related cases in Investor-State Disputes. Categories of such cases include the following sectors of economic activity: ${ }^{62}$

- Access to water cases involving water supply as a public service and sewage services, especially in Latin America-Aguas del Tunariv Bolivia or Urbaser $v$ Argentina, among other cases; ${ }^{63}$

- Chemicals cases-MethanexvUSA;64

- Waste management-MetalcladvMexico; 65

$5^{8}$ See the extensive resource website which also includes codes and statements of individual companies at <www.business-humanrights.org> accessed 20 March 2020. See also International Chamber of Commerce (ICC), 'Business Charter for Sustainable Development', September 2015, also available at <https://iccwbo.org/publication/icc-businesscharter-for-sustainable-development-business-contributions-to-the-un-sustainable-development-goals $>$ accessed 20 March 2020.

59 EuroCommerce, 7 March 2012.

6о АІІв Environmental and Social Framework.

61 See also the work of UNIDO in this field at $<$ www.unido.org $>$.

62 See the informative reports by International Institute for Sustainable Development (IISD), Key Cases from 2000-2010 2011; IISD, Key Cases from the $2010 \mathrm{~s} 2018$.

63 IISD, Key Cases from 2000-2010 2011, 95; IISD, Key Cases from the 2010s 2018, 25-30.

64 IISD, Key Cases from 2000-2010 2011, 81-87.

65 Ibid., 72-80. 
- Mining-Gold Reserve v Venezuela or Pac Rim v El Salvador; ${ }^{66}$

- Oil and gas-Chevron vEcuador; ${ }^{67}$

- Tourism-concerning resorts or wildlife sanctuaries in Kenya, Barbados or Costa Rica;68

- Energy_Vattenfallv Germany; Eiserv Spain; ${ }^{69}$

- Good governance_Churchill Mining v Indonesia; Metal Tech v Uzbekistan; ${ }^{70}$

- Public health—Philip Morris v Uruguay; Philip Morris v Australia. ${ }^{71}$

In combination, these may suffice to demonstrate that in international investment law sustainable development is also on the rise, both in standard-setting through normative instruments and in arbitral decisions in environment and sustainable development-related cases.

\section{4}

\section{Conclusion: Shortcomings, Obstacles and Solutions}

Sections 1 and 2 of this lecture have amply demonstrated that sustainable development has gained currency in international law relatively quickly. A fascinating feature is that sustainable development functions as an integrative concept, having economic, environmental, developmental, social and governance dimensions. Sustainable development is by now well anchored in various sources of international law, most notably treaty law and in other normative instruments, often with a soft law character. In addition, sustainable development is also frequently being addressed in the proceedings and the decisions of international courts and tribunals. Sustainable development is in the process of being integrated in various fields of international law, ranging from international environmental law, human rights law (albeit hesitantly) to international economic law and international investment law. However, a coherent framework to incorporate sustainable development concerns in international law is still lacking. Rather, one notes a disordered patchwork of all kinds of

66 ICSID, Gold Reserve Inc. v Bolivarian Republic of Venezuela 2009; IISD, Key Cases from the 2010s 2018, 36-41.

67 PCA, Chevron Corporation and Texaco Petroleum Corporation $v$ The Republic of Ecuador 2009.

68 IISD, Key Cases from 2000-2010 2011, 162-174; PCA, Peter A. Allard v The Government of Barbados 2012; ICSID, Compañía del Desarrollo de Santa Elena s.A. v The Republic of Costa Rica 1996.

69 ICSID, Vattenfall $A B$ and Others $v$ Federal Republic of Germany 2012; IISD, Key Cases from the 2010 s 2018, 10-14.

70 IISD, Key Cases from the 2010s 2018, 31-35, 61-66.

71 Ibid., 42-47; PCA, Philip Morris Asia Limited v The Commonwealth of Australia 2012. 
international norms in a wide variety of sources with an unequal status, ranging from treaties through judicial decisions to a host of non-binding normative guidelines. Some authors have compared it with an Asian noodle bowl. ${ }^{72}$

For long, international investment law and sustainable development have been at odds with each other. However, that situation has drastically changed in the two recent decades. Foreign investment regulation has started to include linkages with public interest concerns, such as labour standards, environmental protection, sustainable development, public health and animal welfare. Integrated standard-setting is still subject to considerable improvement. There is a need to reform the international investment agreement system in order to address more effectively the sustainable development concerns associated with foreign investment activities. Simultaneously, more efforts should be made to promote that these foreign investment activities assist in achieving sustainable development in a positive way, by introducing environmentally friendly technology and by being instrumental in reducing patterns of unsustainable production and consumption, rather than foreign investment impeding the efforts toward achieving sustainable development.

In one way or another, the international community has to arrive at a more coherent international investment regime, with not only dispute settlement procedures but also with enhanced monitoring, reporting and inspection procedures for reasons of prevention, transparency and accountability. Some have advocated the establishment of a specialized world investment organization. ${ }^{73}$ However appealing, this very idea may itself be contradictory to embedding sustainable development concerns in a host of different chapters of international law, economics and politics. Rather, one should pursue a strongly integrative function of sustainable development as a normative concept. Obviously, this should start with the international investment agreements themselves, bilaterally as well as regionally and multilaterally. They serve as the main global norm supplier of the investment governance system and we are in need of a new generation of these treaties. Obviously, the entire specialized system of international investment law should be made more compatible with sustainable development. However, this will not be sufficient. It is of paramount interest that other regimes such as those in the areas of trade, finance, environment and human rights should also be better attuned to sustainable development. This also calls for an active role of all major stakeholders in international investment regulation and an enabling environment conducive toward such a role in a balanced and coordinated way. Apart from states, the business

72 Chaisse and Hamanaka 2014, 12-17.

73 Butler and Subedi 2017, 43-72. 
community itself, trade unions, civil society organizations and arbitrators should be allowed and even be encouraged to perform their respective roles. Obviously, this includes development institutions such as the Asian Infrastructure Investment Bank specialized in sustainable green financing.

\section{Reference List}

2012 US Model Bilateral Investment Treaty (adopted 11 March 2019) <https://investmentpolicy.unctad.org/international-investment-agreements/treaty-files/2870/ download> accessed 11 March 2020.

2019 Belgium-Luxembourg Economic Union Model Bilateral Investment Treaty (adopted 28 March 2019) <https://investmentpolicy.unctad.org/international-investment-agreements/treaty-files/5854/download $>$ accessed 11 March 2020.

2019 Netherlands Model Investment Agreement (adopted 22 March 2019) <https:// investmentpolicy.unctad.org/international-investment-agreements/treaty -files/5832/download> accessed 11 March 2020.

Asian Infrastructure Investment Bank, Environmental and Social Framework (adopted February 2016, amended February 2019) <https://www.aiib.org/en/policies-strategies/framework-agreements/environmental-social-framework.html> accessed 11 March 2020.

Beharry C L and Kuritzky M E, 'Going Green: Managing the Environment through International Investment Arbitration' (2015) 30(3) American University International Law Review 383 .

Bhuiyan S and others (eds), International Law and Developing Countries: Essays in Honour of Kamal Hossain (Brill Nijhoff 2014).

Bian C and Li Y, 'Elements of Public Policy in the Making of the China-EU Comprehensive Agreement on Investment' in Li Y and others (eds), China, the EU and International Investment Law: Reforming Investor-State Dispute Settlement (Routledge 2020).

Birnie P W and others, International Law and the Environment (3rd edn, OUP 2009).

Business and Human Rights Resource Centre, 'Business \& Human Rights Resource Centre Homepage' (BHRRC) <https://www.business-humanrights.org> accessed 20 March 2020.

Butler N and Subedi S P, 'The Future of International Investment Regulation: Towards a World Investment Organisation?' (2017) 64 Netherlands International Law Review 43.

Chaisse J and Hamanaka S, 'The Investment Version of the Asian Noodle Bowl: The Proliferation of International Investment Agreements' (2014) 128 AD B Working Paper Series on Regional Economic Integration <https://www.adb.org/sites/default/ files/publication/185564/reiwp-128.pdf> accessed 11 March 2020. 
Chevron Corporation and Texaco Petroleum Corporation $v$ The Republic of Ecuador [2009] PCA Case No 2009-23.

Chi M, Integrating Sustainable Development in International Investment Law: Normative Incompatibility, System Integration and Governance Implications (Routledge 2018).

Compañía del Desarrollo de Santa Elena s.A. v The Republic of Costa Rica [1996] ICSID Case No ARB $/ 96 / 1$.

Comprehensive and Progressive Agreement for the Trans-Pacific Partnership (CPTPP) (signed 8 March 2018, entered into force 30 December 2018) <www.mfat.govt.nz/ assets/CPTPP/Comprehensive-and-Progressive-Agreement-for-Trans-Pacific-Partnership-CPTPP-English.pdf $>$ accessed 12 March 2020.

Comprehensive Economic and Trade Agreement between Canada, of the One Part, and the European Union and Its Member States, of the Other Part (CETA between the EU and Canada) (signed 30 October 2016, not yet in force, provisionally applied 21 September 2017).

Convention on Biological Diversity (Biodiversity Convention) (signed 5 June 1992, entered into force 29 December 1993) 1760 UnTS 79.

Convention on International Trade in Endangered Species of Wild Fauna and Flora (CITES) (signed 3 March 1973, entered into force 1 July 1975) 993 UnTs 243.

Convention on Long-Range Transboundary Air Pollution (CLRTAP) (signed 13 November 1979, entered into force 16 March 1983) 1302 UNTS 51.

Convention on Wetlands of International Importance especially as Waterfowl Habitat (Ramsar Convention) (signed 2 February 1972, entered into force 21 December 1975) 996 UnTs 245 .

Dam-de Jong D A, International Law and Governance of Natural Resources in Conflict and Post-Conflict Situations (Cambridge University Press, 2015).

Danish Institute for Human Rights, 'Human Rights and Sustainable Development: A Mutually-Reinforcing Connection' (Fundamental Rights Forum, 13 July 2018) $<$ https://fra.europa.eu/en/frf/blog/human-rights-and-sustainable-developmentmutually-reinforcing-connection $>$ accessed 10 March 2020.

Declaration of the United Nations Conference on Environment and Development (Rio Declaration) (adopted 14 June 1992) UN Doc A/CONF.151/26.

Dupuy R J, 'Declaratory Law and Programmatory Law: From Revolutionary Custom to "soft law"' in Akkerman R J and others (eds), Declaration of Principles: A Quest for Universal Peace (Sijthoff 1977).

EuroCommerce, 'A Renewed EU Strategy 2011-14 for Corporate Social Responsibility: Position Paper' (EuroCommerce, 7 March 2012) <https://www.eurocommerce.eu/ media/7237/position-csr-renewed_csr_strategy_2011-14-07.03.2012.pdf> accessed 11 March 2020.

GoldReserveInc.v Bolivarian Republic of Venezuela [2009] ICs ID Case No ARB(AF)/og/1. 
International Chamber of Commerce, 'Business Charter for Sustainable Development-Business Contributions to the UN Sustainable Development Goals' (ICC, September 2015) Doc No 213/18-13 <https://iccwbo.org/publication/icc-businesscharter-for-sustainable-development-business-contributions-to-the-un-sustainable-development-goals> accessed 20 March 2020.International Financial Corporation, IFC Sustainability Framework (adopted 30 April 2006, amended 1 January 2012) <https://www.ifc.org/wps/wcm/connect/topics_ext_content/ifc_external_cor porate_site/sustainability-at-ifc/policies-standards/sustainability+framework> accessed 11 March 2020.

International Institute for Sustainable Development, International Investment Law and Sustainable Investment: Key Cases from 200o-2010 (IISD 2011) < https://www.iisd.org/ library/international-investment-law-and-sustainable-development-key-cases-2000-2010> accessed 12 March 2020.

International Institute for Sustainable Development, International Investment Law and Sustainable Investment: Key Cases from the 2010 (IISD 2018) < https://www.iisd.org/ library/international-investment-law-and-sustainable-development-key-cases2010s> accessed 12 March 2020.

International Labour Organization, Declaration on Fundamental Principles and Rights at Work and its Follow-up (adopted 18 June 1998, Annex revised 15 June 2010) <https://www.ilo.org/wcmsp5/groups/public/---ed_norm/---declaration/docu ments/normativeinstrument/wcms_716594.pdf> accessed 12 March 2020.

International Labour Organization, Tripartite Declaration of Principles concerning Multinational Enterprises and Social Policy (adopted November 1977, amended 2000, 2006 and 2017) <https://www.ilo.org/wcmsp5/groups/public/---ed_emp/--emp_ent/---multi/documents/publication/wcms_o94386.pdf> accessed 12 March 2020.

Kamau M and others, Transforming Multilateral Diplomacy: The Inside Story of the Sustainable Development Goals (Routledge 2018).

Kube V and Petersmann E U, 'Human Rights Law in International Investment Arbitration' (2016) 11 Asian Journal of wTo \& International Health Law and Policy 65.

Marley J J, 'The Environmental Endangerment Finding in International Investment Disputes' (2014) 46 NYU Journal of International Law and Politics 1003.

Marrakesh Agreement establishing the World Trade Organization (adopted 15 April 1994, entered into force 1 January 1995) 1867 UNTS 3.

Montreal Protocol on Substances that Deplete the Ozone Layer (Montreal Protocol) (signed 16 September 1987, entered into force 1 January 1989) 1522 UNTS 3.

Muchlinski P and others (eds), The Oxford Handbook on International Investment Law (OUP 2008).

New Delhi Declaration of Principles of International Law Relating to Sustainable Development (adopted 6 April 2002) UN Doc A/CONF.199/8. 
Organisation for Economic Co-operation and Development, oEcD Guidelines for Multinational Enterprises (2011 edn, OECD Publishing 2011).

Paris Agreement (signed 12 December 2015, entered into force 4 November 2016) UN Doc FCCC/CP/2015/10/Add. 1 .

Peter A. Allard v The Government of Barbados [2012] PCA Case No. 2012-06.

Philip Morris Asia Limited v The Commonwealth of Australia [2012] PCA Case No 2012-12.

Prislan V and Zandvliet R, 'Mainstreaming Sustainable Development into International Investment Agreements: What Role for Labor Provisions?' in Schill S W and others (eds), International Investment Law: Bridging the Gap (Edward Elgar Publishing 2015).

Ruggie J G, Just Business: Multinational Corporations and Human Rights (W.W. Norton \& Company 2013).

Salini Costruttori S.p.A. and Italstrade S.p.A. v Kingdom of Morocco [200o] ICSID Case No ARB $/ 00 / 4$.

Sands P and Peel J, Principles of International Environmental Law (4th edn, Cambridge University Press 2018).

Sands P, 'International Courts and the Application of the Concept of Sustainable Development' (1999) 3 Max Planck Yearbook of United Nations Law Online 389.

Schrijver N J, Sovereignty over Natural Resources: Balancing Rights and Duties (Cambridge University Press 1997).

Schrijver N J, The Evolution of Sustainable Development in International Law: Inception, Meaning and Status (Martinus Nijhoff Publishers 2008); also in The Hague Academy of International Law (ed), Collected Courses of the Hague Academy of International Law (Brill Nijhoff 2007).

Schrijver NJ and Weiss F G (eds), International Law and Sustainable Development: Principles and Practice (Martinus Nijhoff Publishers 2004).

Schwarzenberger G, Foreign Investment and International Law (Stevens and Sons 1969).

Sohn L B, 'The Stockholm Declaration on the Human Environment' (1973) 14 Harvard International Law Journal 423.

Stephens T, 'Sustainability Discourses in International Courts: What Place for Global Justice' in French D (ed), Global Justice and Sustainable Development (Brill Nijhoff 2010).

Subedi S P, International Investment Law: Reconciling Policy and Principle (3rd edn, Hart Publishing 2016).

Treaty of Lisbon Amending the Treaty on European Union and the Treaty Establishing the European Community (Treaty of Lisbon) (signed 13 December 2007, entered into force 1 January 2009) 2007 O.J. (C 306$) 1$.

UN Convention on the Law of the Sea (UNCLOS) (signed 1o December 1982, entered into force 16 November 1994) 1833 UNTS 3. 
United Nations, 'Guiding Principles on Business and Human Rights: Implementing the United Nations "Protect, Respect and Remedy" Framework' (21 March 2011) UN Doc $\mathrm{A} / \mathrm{HRC} / 17 / 31$.

United Nations, 'Millennium Development Goals Reports' < https://www.un.org/millenniumgoals/reports.shtml> accessed 12 March 2020.United Nations, 'Principles for Responsible Investment' (PRI) < www.unpri.org> accessed 11 March 2020.

United Nations, 'Report of the United Nations Conference on the Human Environment' (UN, 16 June 1972) UN Doc A/CONF.48/14/Rev.1.

United Nations, 'Sustainable Development Goals' (sDGs Knowledge Platform) <https:// sustainabledevelopment.un.org/?menu=1300 $>$ accessed 11 March 2020.

United Nations, 'The Global Compact Leaders Summit 2004-Final Report' (UN, 24 June 2004) <https:/www.unglobalcompact.org/docs/news_events/8.1/summit _rep_fin.pdf $>$ accessed 11 March 2020.

United Nations, 'Transforming Our World: The 2030 Agenda for Sustainable Development' (UN, 25 September 2015) UN Doc A/RES/70/1.

United Nations Development Program, Human Development Report 2003 (OUP 2003).

United Nations Framework Convention on Climate Change (UnFCCC) (signed 9 May 1992, entered into force 21 March 1994) 1771 UNTS 107.

United Nations Industrial Development Organization, 'UNIDo Homepage' (UNIDO) $<$ www.unido.org > accessed 12 March 2020.

United Nations Millennium Declaration (adopted 18 September 200o) UN Doc $\mathrm{A} / \mathrm{RES} / 55 / 2$.

Vattenfall $A B$ and Others $v$ Federal Republic of Germany [2012] ICSID Case No ARB/12/12. Vienna Convention for the Protection of the Ozone Layer (Vienna Convention) (signed 22 March 1985, entered into force 22 September 1988) 1513 UNTS 293.

Weiss T G and Browne S (eds), Post-2015 UN Development: Making Change Happen? (Routledge, 2014).

World Commission on Environment and Development, Our Common Future (oup 1987). 